\title{
HUMAN- AND CLIMATE-INDUCED CHANGES OF MOLLUSC ASSEMBLAGES OF MILLPOND DEPOSITS IN THE VALLEY OF JAROSŁAWIANKA STREAM (POLAND)
}

\author{
JOANNA PIETRUCZUK ${ }^{1}$, ADAM WOJCIECHOWSKI ${ }^{1,2 *}$
}

\begin{abstract}
${ }^{1}$ Department of Environment Analysis, Institute of Geography and Regional Studies, Akademia Pomorska, 76-200 Słupsk, Partyzantów 27, Poland (e-mail: adam.wojciechowski@apsl.edu.pl); AW (i) https://orcid.org/0000-0002-7336-9154

${ }^{2}$ Present affiliation: Chair of Earth and Environmental Sciences, Institute of Biology and Earth Sciences, Akademia Pomorska, 76-200 Słupsk, Partyzantów 27, Poland

*corresponding author
\end{abstract}

\begin{abstract}
Deposits from a millpond in the Jarosławianka Stream valley (Sławno Plain, NW. Poland) were subject to malacological analysis in order to reconstruct the history of environmental transformations of the pond from its establishment in 1351 to the end of its functioning in 1960. Thirty five mollusc taxa occurred in the pond during its functioning: 21 taxa of water snails, 11 bivalves, and 3 terrestrial snails. Six phases of development of the pond were distinguished, based on the mollusc assemblages: phase I (1351-1450 CE) - very favourable habitat conditions, high species richness and diversity; phase II (14501490 CE) - deterioration of habitat conditions - decrease in the number of species and individuals; phase III (1490-1590 CE) - improving conditions and reappearance of species which had occurred in the pond in phase I; phase IV (1590-1750 CE) - the least favourable conditions and poor malacofauna in terms of species number and abundance; phase V (1750-1790 CE) - renewed development of the malacofauna; phase VI (after $1790 \mathrm{CE}$ ) - end of functioning of the pond. The phases of pond development were associated with hydrological transformations, resulting from climatic factors and human economic activity.
\end{abstract}

KEY WORDS: mollusc assemblages; millpond deposits; last millennium; Jarosławianka Stream; Pomerania; Poland

\section{INTRODUCTION}

Anthropogenic water bodies, including ponds of various origins, play an important role in modern landscape. Their environmental importance involves an increase in the habitat diversity in areas with no natural water bodies, in degraded or human-transformed areas, and thus preservation of, and often also increase in biodiversity through provision of new favourable habitats for many plant and animal species (WOOD \& BARKER 2000, STRZELEC \& SERAFIŃSKI 2004, CÉRÉGHINO et. al. 2008).

From the ecological point of view, ponds are very comfortable objects of research on colonisation of water bodies, the effect of environmental factors on the structure of plant and animal communities, and the area effect on the occurrence and diversity of particular groups of animals (SPYRA et al. 2007).
Due to their specific hydrological and edaphic conditions, ponds are subject to numerous malacological studies (e.g. STRZELEC 1993, WOOD \& BARKER 2000, KOŁODZIEJCZYK \& DOŁĘGA 2004, STRZELEC \& SERAFIŃSKI 2004, SPYRA et al. 2007, STRZELEC et al. 2014). In contrast to research on modern malacocoenoses, studies on mollusc assemblages of erstwhile ponds are relatively rare, especially those involving complete succession of malacofauna from the establishment of the water body to its filling. This type of studies, considering mollusc assemblages, their species composition, and additionally textural and structural properties of the sediments, make it possible to assess the environmental transformations in a long time perspective (SZWARCZEWSKI 2003). 
The research was conducted in a millpond on the lower section of the Jarosławianka Stream, near its mouth to the Wieprza River, between the villages of Stary Kraków and Kowalewice, Poland. According to ROSENOW (1934), the mill was established by the Knights Hospitaller of St. John of Jerusalem in 1351, and functioned until 1960. At present, the remains of the mill include its foundations, fragments of the wooden weir, the earth dam, and sediments deposited in the former millpond.

The Jarosławianka Stream valley and the area of the former millpond were subject of geomorphological (FLOREK \& TYLMAN 2013), pedological (JONCZAK 2010, JONCZAK \& FLOREK 2013), archaeological (RĄCZKOWSKI \& BANASZEK 2013) and botanical re- search (SOBISZ 2013), and subfossil Cladocera analyses (NISKA 2013). Particularly the latter analysis permitted the comparison of the cladoceran and molluscan assemblages in the analysed sediment profiles, and lent support to the palaeoenvironmental conclusions.

The primary objective of this study was to characterise the mollusc assemblages occurring in the sediments of the millpond in the Jarosławianka Stream valley. These considerations provided the basis for the reconstruction of environmental conditions at particular phases of development of the pond, beginning from its establishment until the end of its existence, in relation to the climatic and hydrological transformations of the last 650 years.

\section{STUDY AREA}

The Jarosławianka Stream is a left-bank tributary of the Lower Wieprza River, with the length of $3.7 \mathrm{~km}$ and catchment area of $5.74 \mathrm{~km}^{2}$ (JONCZAK \& FLOREK 2013). It is located in NW. Poland in the
Sławno Plain mesoregion (KONDRACKI 2009) (Fig. 1). The middle and lower sections of the Jarosławianka Stream valley are more than 10 metres deep and cut in the surface deposits of varied origin: glacial
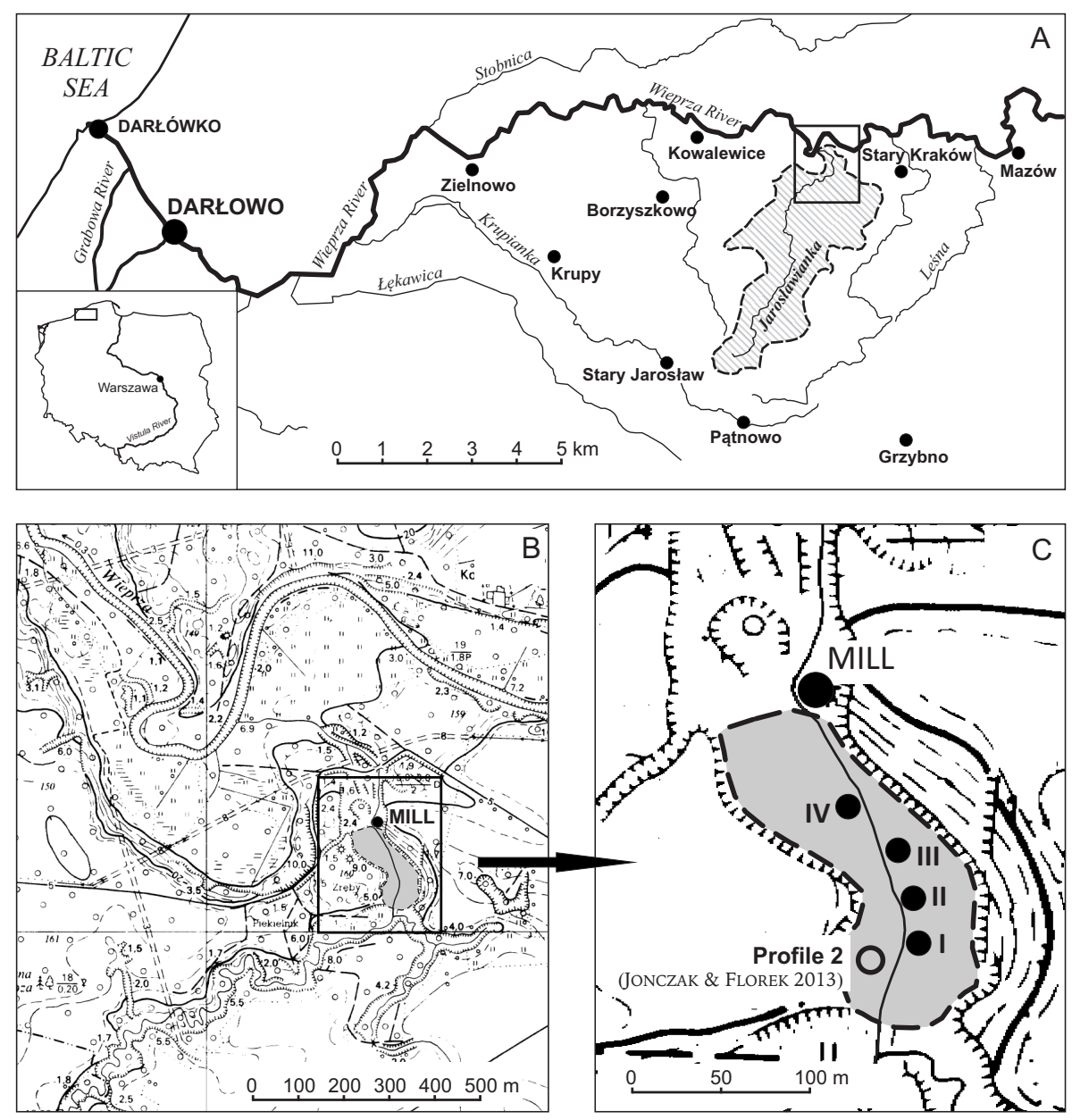

Fig. 1. A - Location of Jarosławianka Stream catchment (hatched) in Sławno Plain; B - Location of the millpond in the mouth section of Jarosławianka Stream; C - Location of profiles JAR I, JAR II, JAR III, JAR IV and profile 2 (JONCZAK \& FLOREK 2013) 
tills, sands and gravels of kames, silty-clay glacio-lacustrine formations, and the underlying older marl loams. On the boundary of marl loams and younger deposits, inter-layers of sands occur, constituting an aquifer feeding the river (JONCZAK \& FLOREK 2013). A characteristic feature of the valley is the high inclination of the longitudinal profile of the river $(7.65 \%)$, benefitting its use for hydro-energy production.

The catchment of the Jarosławianka Stream valley is overgrown by Subatlantic fresh pine forests (Leucobryo-Pinetum) and continental mixed forests (Querco roboris-Pinetum), originating from the transformation of the original beech forests from the assemblage Fagion sylvaticae at the boundary of the 19th and 20th century (PLIT 2009, SOBISZ 2013). The floor of the valley and the surface of the former millpond

\section{MATERIAL AND METHODS}

The field survey was carried out during four expeditions from March to October 2016, with four excavations along the channel of the Jarosławianka Stream, and sampling four sediment cores with a length of 200 to $270 \mathrm{~cm}$. The samples were taken at 5-10 cm intervals, depending on the lithology of the sediments. A total of 132 samples with a volume ca. $500 \mathrm{~cm}^{3}$ were collected for malacological analysis. At the laboratory, the samples were rinsed on a sieve with $0.25 \mathrm{~mm}$ mesh. Silty samples and those strongly contaminated with organic matter were heated in $5 \% \mathrm{KOH}$ solution. The mollusc remains were mostly well preserved, permitting precise species identification. Numerous fragments of crushed shells were also found in the sediments; these could be identified only to the genus or family levels. The shell fragments which enabled indisputable identification were recalculated into whole specimens in accordance with the formula developed by ALEXANDROWICZ \& ALEXANDROWICZ (2011).

The malacological analysis followed LOŽEK (1964) and AlEXANDROWICZ \& ALEXANDROWICZ (2011). The mollusc species were classified into four ecolog-

\section{RESULTS}

\section{GEOLOGICAL SETTING}

In lithological terms, the analysed section of the Jarosławianka Stream catchment is built of four deposit series: fluvial sands and silty-clay, peaty gley soils, millpond sediments, as well as overbank sands and soils constituting the uppermost layer of the deposit series (Fig. 2).

The millpond bed is composed of fluvial sands and silty clay, covered by peaty gley soils in the south- are occupied by ash-alder riparian forest (FraxinoAlnetum) with high species richness and complex layer structure. The dominant species in the tree stand is common alder (Alnus glutinosa), with admixtures of common oak (Quercus robur), European ash (Fraxinus excelsior), and less frequent Norway spruce (Picea abies) and silver birch (Betula pendula). As many as 468 species of vascular plants occur in the small Jarosławianka Stream catchment, including 27 protected species (SOBISZ 2013).

The lower section of the Jarosławianka Stream valley, together with the former millpond, is included in the European Ecological Natura 2000 Network Programme of protected sites, as "Wieprza and Studnica Valley" (PLH 220038).

ical groups in accordance with the scheme presented by AleXANDROWICZ \& AlEXANDrowicZ (2011): L - terrestrial species; $S$ - species typical of small, periodic, and strongly vegetated water bodies; $\mathrm{P}$ - species of permanent water bodies; $\mathrm{R}$ - rheophilous species.

Percent malacological diagrams presenting the occurrence of species were developed in Tilia and Tilia Graph software (GRIMM 1990). Shannon diversity $(\mathrm{H})$ and evenness indices were calculated with the PAST statistical package (HAMMER et al. 2001). The conventional radiocarbon dates (JONCZAK \& FLOREK 2013) were calibrated with OxCal 4.4 software (BRONK RAMSEY 2009). The IntCal20 (REIMER et al. 2020) atmospheric curve was applied for date calibration.

To determine which mollusc assemblages responded to climate changes, we compared the number of specimens and taxa with the well-known temperature changes over Europe between 1300 and ca. 1900 CE (LUTERBACHER et al. 2016). The comparison used the temperature reconstruction based on Bayesian hierarchical modelling (in the original paper by LUTERBACHER et al. 2016 - blue line).

ern and eastern parts (JONCZAK \& FLOREK 2013). According to radiocarbon dating, the age of the uppermost layer of the soils is $750 \pm 50$ years BP (MKL1335) (JONCZAK \& FLOREK 2013). The fluvial sands and silty clay are covered by millpond sediments of spatially variable thickness, with the bottom layer dated as $590 \pm 40$ years BP (MKL-513) (JONCZAK \& FLOREK 2013), which closely corresponds with historical data of the establishment of the mill and pond in 1351 (Table 1). In the lower part, the millpond 
sediments are developed in the form of black muds with a rich malacofauna deposited at the depth of $140-185 \mathrm{~cm}$ in profile JAR I to $200-235 \mathrm{~cm}$ in profile JAR IV. The northward decrease in the depth range of the series corresponds with the slope inclination of the valley of $4.11 \%$ (FLOREK \& TYLMAN 2013).

The upper series of millpond sediments, developed in the form of brown muds, shows bedded structure of fluvial-limnic sedimentation, and the possibility of periodic sediment supply from the slope (FLOREK \& TYLMAN 2013). Two oak trunks are embedded within this deposit series, at the depth of ca. 85-95 cm. Based on dendrochronological dating, they were cut in $1740 \mathrm{CE}$ (MKL-551) and $1754 \mathrm{CE}$ (MKL-552) (JONCZAK \& FLOREK 2013).

A characteristic feature of the muddy-sandy deposits of the millpond is their vertical and spatial variation in textural and geochemical terms. The average grain diameter of the deposits varies from 3.85 to 6.04 phi, and sorting from 1.23 to 1.86 . They also show low density $\left(0.42-1.32 \mathrm{~g} \mathrm{~cm}^{-3}\right)$ and high porosity of up to $81.0 \%$. They are mostly of mineral-organic character, containing up to $17.55 \%$ organic matter, and up to $7.95 \%$ organic carbon. The muddy-silty sediments of the millpond are nitrogen-rich (mean nitrogen content $0.43 \%$ ), and moderately rich in phosphorus (mean content $0.12 \%$ ). The reaction of the sediments varies from alkaline (lower part of the profiles) to strongly acidic in the upper part (depth 0-70 cm) (JONCZAK \& FLOREK 2013).

The uppermost deposit series is formed of overbank deposits and modern soils with a thickness ranging from $30 \mathrm{~cm}$ in profile JAR IV to $70-90 \mathrm{~cm}$ in profiles JAR I, JAR II and JAR III.

Table 1. Results of calibration of conventional radiocarbon dates of millpond sediments in profile 2 (JONCZAK \& FLOREK 2013) to calendar years, expressed as CE (Common Era). Location of samples as in Fig. 2

\begin{tabular}{cccccr}
\hline $\begin{array}{c}\text { Depth } \\
(\mathrm{cm})\end{array}$ & \multirow{2}{*}{ Material } & $\begin{array}{c}\text { Laboratory } \\
\text { number }\end{array}$ & $\begin{array}{c}\text { Radiocarbon age } \\
{ }^{14} \text { C years BP }\end{array}$ & $\begin{array}{c}\text { Calibrated age } \\
\text { years CE }\end{array}$ & \multirow{2}{*}{ Probability } \\
\hline $170-174$ & brown-black muds & MKL-513 & $590 \pm 40$ & $1300-1420$ & $95.4 \%$ \\
$180-185$ & peaty gley soil & MKL-1335 & $750 \pm 50$ & $1179-1191$ & $1.6 \%$ \\
& & & & $1205-1309$ & $88.1 \%$ \\
& & & $1362-1386$ & $5.8 \%$ \\
\hline
\end{tabular}

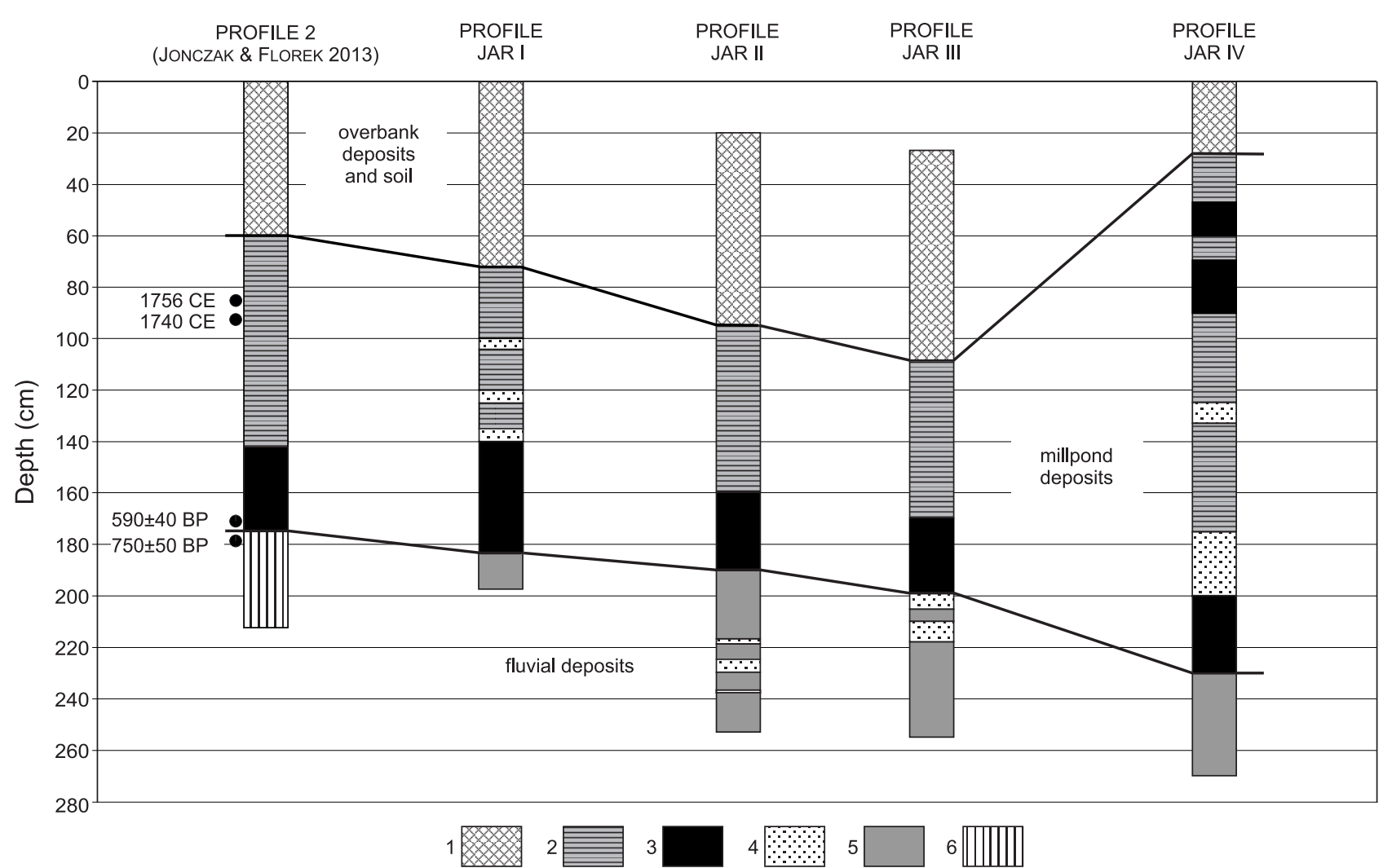

Fig. 2. Lithology of millpond deposits: 1 - overbank deposits and soil, 2 - layered sandy silts, 3 - brown-black muds, 4 varigrained sands, 5 - fluvial sands and silty-clay, 6 - peaty gley soil. Radiocarbon and dendrochronological dates after JONCZAK \& FLOREK (2013) 


\section{MALACOLOGICAL PROFILES}

The composition of the malacofauna of the millpond sediments of Jarosłowianka Stream valley is shown in Table 2. Mollusc shells occurred in 43 samples, exclusively within the brown-black muds. The remaining samples contained no malacofauna, or only small shell fragments, impossible to identify even to the family level. The total number of specimens in four profiles was 2,770, representing 35 taxa (Table 2). Of these, 21 were freshwater snails, 11 were bivalves of the families Sphaeriidae and Unionidae, and three were terrestrial species. The number of taxa varied among the profiles, ranging from 12 in profile JAR IV to 30 in profile JAR II (Table 2). The number of individuals varied from one in the numerous samples of profile JAR IV to 220 and 245 in two bottom samples of profile JAR I.

Table 2. Composition of malacofauna in profiles JAR I, JAR II, JAR III and JAR IV from the millpond sediments of Jarosławianka Stream valley. Symbols of ecological groups: $\mathrm{L}$ - terrestrial species; $\mathrm{S}$ - species typical of small, periodically disappearing, and strongly overgrowing water bodies; P - species inhabiting permanent water bodies; R - rheophilous species

\begin{tabular}{|c|c|c|c|c|c|c|c|c|c|c|c|c|}
\hline \multirow{2}{*}{ No } & \multirow{2}{*}{$\begin{array}{l}\text { Ecological } \\
\text { group }\end{array}$} & \multirow{2}{*}{ Taxon } & \multicolumn{2}{|c|}{ JAR I } & \multicolumn{2}{|c|}{ JAR II } & \multicolumn{2}{|c|}{ JAR III } & \multicolumn{2}{|c|}{ JAR IV } & \multicolumn{2}{|c|}{ Total } \\
\hline & & & No & $\%$ & No & $\%$ & No & $\%$ & No & $\%$ & No & $\%$ \\
\hline 1 & $\mathrm{~L}$ & Succinea putris (Linnaeus, 1758) & 31 & 3.3 & 81 & 8.7 & 72 & 11.9 & 9 & 3.0 & 193 & 7.0 \\
\hline 2 & $\mathrm{~L}$ & Cochlicopa lubrica (O. F. Müller, 1774) & - & - & 2 & 0.2 & - & - & - & - & 2 & 0.1 \\
\hline 3 & $\mathrm{~L}$ & Monachoides incarnatus (O. F. Müller, 1774) & 1 & 0.1 & - & - & - & - & - & - & 1 & 0.0 \\
\hline 4 & $S$ & Valvata cristata O. F. Müller, 1774 & 3 & 0.3 & 3 & 0.3 & 3 & 0.5 & - & - & 9 & 0.3 \\
\hline 5 & $S$ & Valvata macrostoma Mörch, 1864 & 12 & 1.3 & 52 & 5.6 & 9 & 1.5 & 1 & 0.3 & 74 & 2.7 \\
\hline 6 & $S$ & Bithynia leachi (Sheppard, 1823) & 50 & 5.4 & 5 & 0.5 & 6 & 1.0 & 9 & 3.0 & 70 & 2.5 \\
\hline 7 & $S$ & Stagnicola palustris (O. F. Müller, 1774) & 5 & 0.5 & 8 & 0.9 & - & - & - & - & 13 & 0.5 \\
\hline 8 & $S$ & Stagnicola corvus (Gmelin, 1791) & - & - & 6 & 0.6 & - & - & - & - & 6 & 0.2 \\
\hline 9 & S & Galba truncatula (O. F. Müller, 1774) & 3 & 0.3 & 3 & 0.3 & - & - & - & - & 6 & 0.2 \\
\hline 10 & $S$ & Planorbis planorbis (Linnaeus, 1758) & 51 & 5.5 & 145 & 15.5 & - & - & - & - & 196 & 7.1 \\
\hline 11 & $S$ & Gyraulus rossmaessleri (Auerswald, 1851) & 11 & 1.2 & 22 & 2.4 & 7 & 1.2 & - & - & 40 & 1.4 \\
\hline 12 & $S$ & Segmentina nitida (O. F. Müller, 1774) & - & - & 3 & 0.3 & 4 & 0.7 & - & - & 7 & 0.3 \\
\hline 13 & $S$ & Pisidium milium Held, 1836 & 7 & 0.7 & 19 & 2.0 & 15 & 2.5 & - & - & 41 & 1.5 \\
\hline 14 & $S$ & Pisidium pseudosphaerium Schlesch, 1947 & 26 & 2.8 & 47 & 5.0 & 14 & 2.3 & - & - & 87 & 3.1 \\
\hline 15 & $S$ & Pisidium pulchellum Jenyns, 1832 & - & - & 1 & 0.1 & - & - & - & - & 1 & 0.0 \\
\hline 16 & $S$ & Pisidium obtusale (Lamarck, 1818) & 1 & 0.1 & 1 & 0.1 & 1 & 0.2 & - & - & 3 & 0.1 \\
\hline 17 & $\mathrm{P}$ & Valvata piscinalis O. F. Müller, 1774 & 79 & 8.5 & 93 & 9.9 & 48 & 7.9 & 9 & 3.0 & 229 & 8.3 \\
\hline \multirow[t]{2}{*}{18} & $\mathrm{P}$ & Bithynia tentaculata (Linnaeus, 1758) & 28 & 3.0 & 58 & 6.2 & 24 & 4.0 & - & - & 110 & 4.0 \\
\hline & & (opercula) & 155 & 16.6 & 59 & 6.3 & 67 & 11.1 & 220 & 74.1 & 501 & 18.1 \\
\hline 19 & $\mathrm{P}$ & Lymnaea stagnalis (Linnaeus, 1758) & 14 & 1.5 & 21 & 2.2 & 26 & 4.3 & 11 & 3.7 & 72 & 2.6 \\
\hline 20 & $\mathrm{P}$ & Radix labiata (Rossmässler, 1835) & 94 & 10.1 & 43 & 4.6 & 86 & 14.2 & 13 & 4.4 & 236 & 8.5 \\
\hline 21 & $\mathrm{P}$ & Gyraulus albus (O. F. Müller, 1774) & 75 & 8.0 & 54 & 5.8 & 24 & 4.0 & 4 & 1.3 & 157 & 5.7 \\
\hline 22 & $\mathrm{P}$ & Gyraulus crista (Linnaeus, 1758) & 31 & 3.3 & 42 & 4.5 & 26 & 4.3 & 14 & 4.7 & 113 & 4.1 \\
\hline 23 & $\mathrm{P}$ & Bathyomphalus contortus (Linnaeus, 1758) & 2 & 0.2 & 1 & 0.1 & 1 & 0.2 & - & - & 4 & 0.1 \\
\hline 24 & $\mathrm{P}$ & Hippeutis complanatus (Linnaeus, 1758) & 9 & 1.0 & 21 & 2.2 & 3 & 0.5 & 2 & 0.7 & 35 & 1.3 \\
\hline 25 & $\mathrm{P}$ & Acroloxus lacustris (Linnaeus, 1758) & 64 & 6.9 & 47 & 5.0 & 10 & 1.7 & - & - & 121 & 4.4 \\
\hline 26 & $\mathrm{P}$ & Sphaerium corneum (Linnaeus, 1758) & - & - & 1 & - & - & - & - & - & 1 & 0.0 \\
\hline 27 & $\mathrm{P}$ & Pisidium casertanum (Poli, 1791) & 26 & 2.8 & 18 & 1.9 & 23 & 3.8 & - & - & 67 & 2.4 \\
\hline 28 & $\mathrm{R}$ & Anodonta anatina (Linnaeus, 1758) & - & - & 1 & 0.1 & - & - & - & - & 1 & 0.0 \\
\hline 29 & $\mathrm{R}$ & Pisidium nitidum Jenyns, 1832 & 47 & 5.0 & 23 & 2.5 & 85 & 14.1 & - & - & 155 & 5.6 \\
\hline 30 & $\mathrm{R}$ & Pisidium subtruncatum Malm, 1855 & 71 & 7.6 & 45 & 4.8 & 50 & 8.3 & - & - & 166 & 6.0 \\
\hline 31 & $\mathrm{R}$ & Pisidium personatum Malm, 1855 & 6 & 0.6 & 10 & 1.1 & - & - & - & - & 16 & 0.6 \\
\hline 32 & & Valvata sp. & - & - & - & - & - & - & 1 & 0.3 & 1 & 0.0 \\
\hline 33 & & Pisidium sp. & 7 & 0.7 & - & - & - & - & - & - & 7 & 0.3 \\
\hline 34 & & Lymnaeidae sp. & 25 & 2.7 & - & - & - & - & - & - & 25 & 0.9 \\
\hline 35 & & Planorbidae sp. & - & - & - & - & - & - & 4 & 1.3 & 4 & 0.1 \\
\hline \multicolumn{3}{|c|}{ Total number of specimens } & 934 & 100 & 935 & 100 & 604 & 100 & 297 & 100 & 2,770 & 100 \\
\hline \multicolumn{3}{|c|}{ Total number of taxa } & 27 & & 30 & & 21 & & 12 & & 35 & \\
\hline
\end{tabular}




\section{PROFILE JAR I}

The assemblage of the profile included 934 individuals of 27 taxa (2 terrestrial species, 17 aquatic snails, and 8 bivalve taxa). The molluscs occurred exclusively in the lower part of the profile at the depth of 115-185 cm, within the black muds and muds with sand inter-layers (Fig. 3). Four local mollusc assemblage zones (LMAZ) were distinguished. The bottom part of the profile (LMAZ JAR I-1, 170-185 $\mathrm{cm})$ was dominated by Bithynia tentaculata opercula (max. $28.9 \%$ of all individuals), Valvata piscinalis (21.0\%), Radix labiata (14.4\%) and Acroloxus lacustris $(12.7 \%)$. Species typical of small and strongly vegetated water bodies (i.a. Bithynia leachi, Valvata cristata, Valvata macrostoma, Stagnicola palustris, Galba truncatula) accounted for $14.1 \%$ of all specimens, and rheophilous species for $11.6 \%$. Terrestrial taxa constituted a small proportion and were represented by Monachoides incarnatus, a Central- and SouthEuropean species, rarely encountered in northern Poland (WIKTOR 2004), and characteristic of warm periods (ALEXANDROWICZ 1987, JURIČKOVA et al. 2014), and by the hygrophilous Succinea putris.

At the depth of 162.5-170 cm (LMAZ JAR I-2) the number of taxa and individuals decreased (Fig. 3 ). The primary components of this assemblage were drought-resistant species: Planorbis planorbis (38.3\%), R. labiata $(23.4 \%)$, B. tentaculata $(11.4 \%)$ and Gyraulus rossmaessleri $(5.2 \%)$, suggesting periodic emptying of the pond.

The next LMAZ JAR I-3 $(140-162.5 \mathrm{~cm})$ showed an increase in the number of taxa and individuals, and dominance of Gyraulus albus (19.6\%), R. labiata (19.5\%), and - in the uppermost part of the level Pisidium nitidum $(40.1 \%)$. B. leachi, B. tentaculata, $V$. piscinalis, Gyraulus crista and Pisidium pseudosphaerium constituted accessory components. From the depth of $155 \mathrm{~cm}$, a decrease in the number of species was observed. The molluscs were represented by several individuals of $B$. leachi, and fragments of shells of Pisidium sp. (Fig. 3).

The uppermost level (LMAZ JAR I-4, 115-135 $\mathrm{cm}$ ) covering sandy-muddy sediments contained several individuals of $V$. macrostoma, $R$. labiata, as well as shells and opercula of $B$. tentaculata.

The Shannon diversity index $(\mathrm{H})$ varied from $0.69-0.80$ in the species-poor and low-density assemblages of the sandy silts at the depth of 115-145 cm to 2.07-2.59 in the assemblages of the brown-black muds. The evenness index in JAR I profile was high and ranged from 0.73 to 1.00 . Only in two samples at the depth of $175-180 \mathrm{~cm}$ and $158-170$, the values of the evenness index were 0.53 and 0.59 (Fig. 3).



Fig. 3. Percent mollusc species composition in the sediments of profile JAR I: L - terrestrial snails, S - species typical of small, periodically disappearing, and strongly overgrowing water bodies, $\mathrm{P}$ - species inhabiting permanent water bodies, $\mathrm{R}$ - rheophilous species, $\mathrm{H}$ - Shannon's diversity index, $\mathrm{E}$ - evenness index, LMAZ - local mollusc assemblage zone. Lithological signatures as in Fig. 2 


\section{PROFILE JAR II}

Four local assemblage zones (LMAZ) were distinguished in the profile. The bottom LMAZ JAR II-1 $(175-190 \mathrm{~cm})$ comprised 24 taxa represented by 437 individuals, dominated by $V$. piscinalis $(23.5 \%$ on average), opercula of $B$. tentaculata constituting $13 \%$ of all individuals, $V$. macrostoma (8.4\%), A. lacustris (8\%) and S. putris reaching a maximum of $11.9 \%$ in the level (Fig. 4).

LMAZ JAR II-2 $(170-175 \mathrm{~cm})$ showed a distinct decrease in the number of individuals (111) and taxa (11), particularly species dwelling on aquatic plants. They were replaced by species inhabiting seasonal, drying water bodies: P. planorbis $(43.6 \%)$, G. rossmaessleri (15.7\%), S. palustris (5.1\%) and Stagnicola corvus (6.3\%); they occurred exclusively within this level. Such a composition of the assemblage suggests that, within this level, the millpond was probably periodically devoid of water.

The next level (LMAZ JAR II-3; 160-170 cm) was characterised by an increase in diversity; 450 individuals represented 26 taxa, among others $R$. labiata, $V$. cristata, V. macrostoma, G. crista, P. pseudosphaerium, Pisidium milium and two individuals of Cochlicopa lubrica (Fig. 4).

From the depth of $160 \mathrm{~cm}$ (LMAZ JAR II-4), the change in sediment lithology was accompanied by a change in the number of individuals, and disappearance of species typical of shallow and much vegetated water bodies. The level was dominated by euryoecious species: R. labiata (23.5\%), $V$. piscinalis $(16.7 \%)$ and $B$. tentaculata (25\%). In the uppermost level, at the depth of 142-147 cm, only single individuals of Pisidium casertanum and P. subtruncatum occurred (Fig. 4).

For the JAR II profile the values of the Shannon diversity $(\mathrm{H})$ and evenness indices were 2.10-2.68 and $0.45-0.77$, respectively. Only in the sample from the depth of 142.5-147.5 cm, Shannon's diversity index was 0.69 and the evenness index -1.00 (Fig. 4).

\section{PROFILE JAR III}

The sequence began at the depth of $205 \mathrm{~cm}$ with an assemblage with a large proportion of $R$. labiata (74.2\% of total fauna) and an admixture of $S$ putris (22.6\%) and several individuals of Segmentina nitida, G. crista and P. casertanum (Fig. 5). From the depth of $200 \mathrm{~cm}$ (LMAZ JAR III-2), with the beginning of sedimentation of black muds, the structure of the assemblage changed. Eighteen taxa suddenly appeared, represented by 464 individuals. The assemblage was dominated by species characteristic of permanent water bodies: B. tentaculata (20.9\%), V. piscinalis $(14.3 \%)$, R. labiata (16.6\%), G. crista (14.3\%) and species typical of shallow and much vegetated littoral zones: B. leachi, $V$. cristata, $V$. macrostoma, Pisidium obtusale and $P$. milium reaching a total of $13.3 \%$. The proportion of the hygrophilous $S$. putris was also substantial, reaching 20-22\% within this level (Fig. 5).

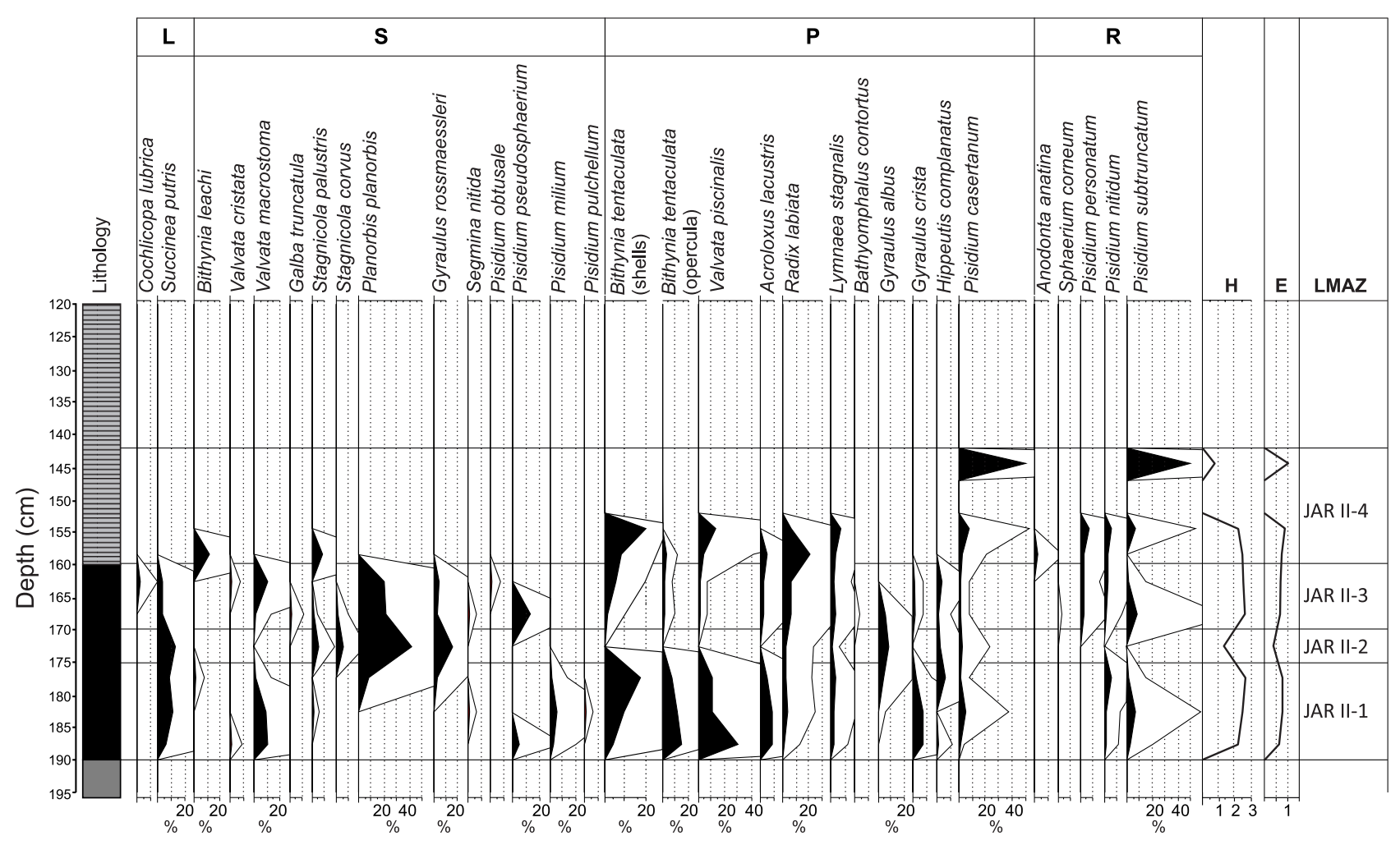

Fig.4. Percent mollusc taxa composition in the sediments of profile JAR II. For explanations see Fig. 3 


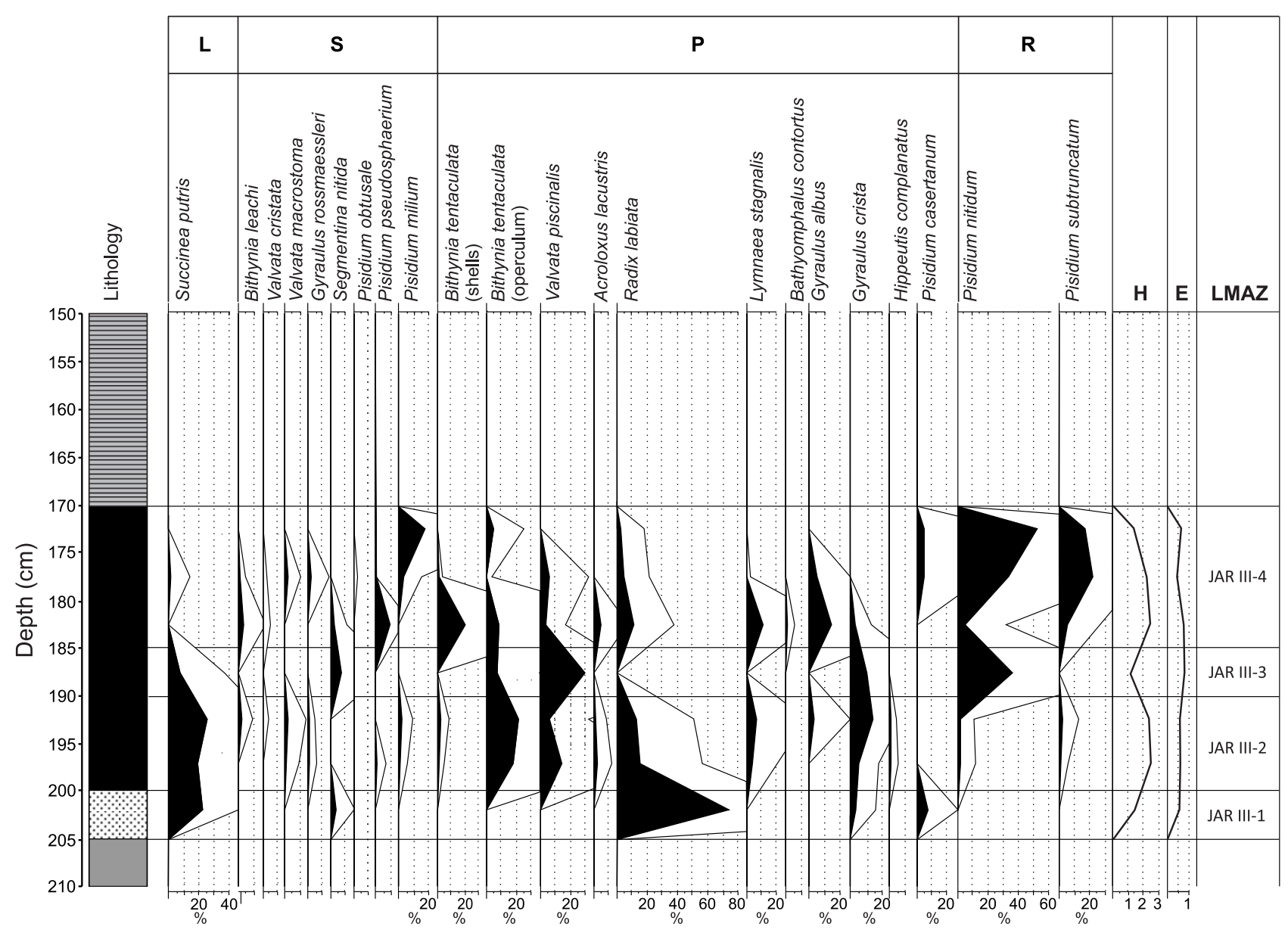

Fig. 5. Percent mollusc taxa composition in the sediments of profile JAR III. For explanations see Fig. 3

At the level of 185-190 cm (LMAZ JAR III-3), an evident decrease in the number of taxa (6) and individuals (14) was observed. The primary components of the assemblage were P. nitidum (35.7\% of the total fauna), as well as $V$. piscinalis $(28.6 \%), G$. crista (14.3\%); there were single individuals of $S$. putris, $S$. nitida and opercula of $B$. tentaculata. A decrease in the number of species and individuals in this part of the profile suggests a deterioration of habitat conditions and an increase in the flow of the Jarosławianka Stream.

The primary components of the assemblage in the uppermost part of the profile (LMAZ JAR III-4, $170-185 \mathrm{~cm}$ ) were bivalves: $P$. nitidum, $P$. subtruncatum, $P$. pseudosphaerium, $P$. casertanum, $P$. milium, and P. obtusale - constituting a total of $55.5 \%$ of the fauna. Besides, the assemblage comprised shells and opercula of B. tentaculata (17.2\%), G. albus (9.8\%), R. labiata $(7.9 \%), V$. piscinalis (4.9\%), G. rossmaessleri (2.3\%), $V$. macrostoma $(0.6 \%)$, B. leachi $(0.6 \%)$, Lymnaea stagnalis (0.6\%) and A. crista (0.6\%) (Fig. 5).

The highest values of the Shannon diversity index $(\mathrm{H})$ in the profile varied from 2.16 to 2.35 and were found in almost all samples, while the lowest (1.051.57) were recorded for assemblages of the lower, middle and upper part of the profile. The evenness index for the entire profile varied between 0.48 and 0.80 (Fig. 5).

\section{PROFILE JAR IV}

It was located in the northern part of the former mill complex. It covered the longest $(200 \mathrm{~cm})$ sequence of muds and sandy-muddy sediments, although compared to the other profiles it contained the smallest number of species and individuals. Only 297 individuals belonging to 12 taxa were found throughout the profile. The assemblage was dominated by $B$. tentaculata (exclusively opercula), constituting $74.1 \%$ of all individuals.

The malacofauna occurred in three levels (Fig. 6). The oldest one (LMAZ JAR IV-1) was located at the depth of 200-230 cm within the black muds. It contained 70 individuals, dominated by R. labiata and G. crista (both species represented $20.4 \%$ ), as well as $S$. putris (14.3\%). Moreover, the assemblage of this level included opercula of B. tentaculata $(10.2 \%), V$. piscinalis $(10.2 \%)$, L. stagnalis $(10.2 \%)$, G. albus $(8.2 \%)$, H. complanatus $(4.1 \%)$, and fragments of planorbid shells (2.0\%) (Fig. 6). 


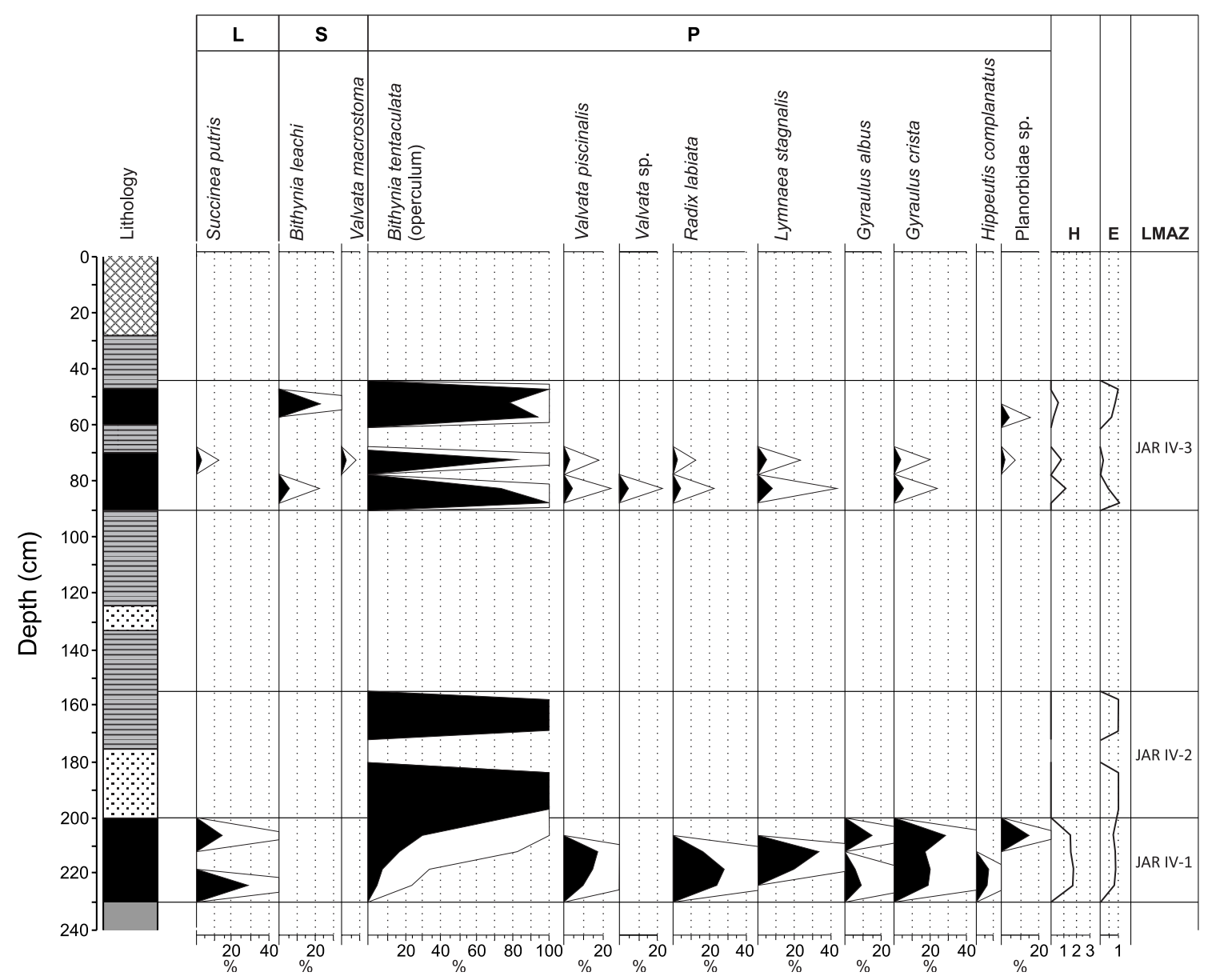

Fig. 6. Percent mollusc taxa composition in the sediments of profile JAR IV. For explanations see Fig. 3

The middle part of the profile was devoid of molluscs. Only LMAZ JAR IV-2 $(155-200 \mathrm{~cm})$, covering the layer of sandy muds and sands, contained single opercula of $B$. tentaculata.

The youngest level (LMAZ JAR IV-3) was deposited at the depth of $45-90 \mathrm{~cm}$ within the layer of black muds. It contained almost exclusively opercula of $B$. tentaculata, constituting $85.4 \%$ of the total fauna, with an admixture of B. leachi $(4.0 \%)$, L. stagnalis (2.7\%), G. crista (1.8\%), $V$. piscinalis (1.8\%), $R$. labiata (1.3\%), S. putris (0.9\%), V. macrostoma (0.4\%), and several fragments of shells of Valvata sp. and Planorbidae sp. (1.7\%) (Fig. 6).

\section{DISCUSSION}

\section{DEVELOPMENT PHASES OF THE MILLPOND}

The diversity of the mollusc assemblages, lithological features, and comparison with the record of frequency of cladoceran species (NISKA 2013) indicate six phases of development of the millpond (Fig. 7). The time frames of particular phases were determined based on historical data (ROSENOW 1934), radiocarbon and dendrochronological dating
The small number of species and individuals present in the JAR IV profile resulted in low values of the Shannon diversity index, ranging from 0.00 (one species) to 1.81 . The highest values of the $\mathrm{H}$ index were recorded in the lower layer of brown-black muds, where they ranged from 1.55 to 1.81 , and the lowest (0.00) in the middle part of the profile, in which there were single opercula of $B$. tentaculata. The evenness index ranged from $0.28-0.58$ in the upper part of the profile to $0.82-1.00$ in the remaining samples (Fig. 6).

(JONCZAK \& FLOREK 2013), and correlations with the record of land summer temperature anomaly in Europe over the last 700 years (LUTERBACHER et al. 2016).

Phase I ( w a r m period;

$1351-1450$ C E )

The beginning of the development of the millpond fell on the mild climate of the mid-14th cen- 


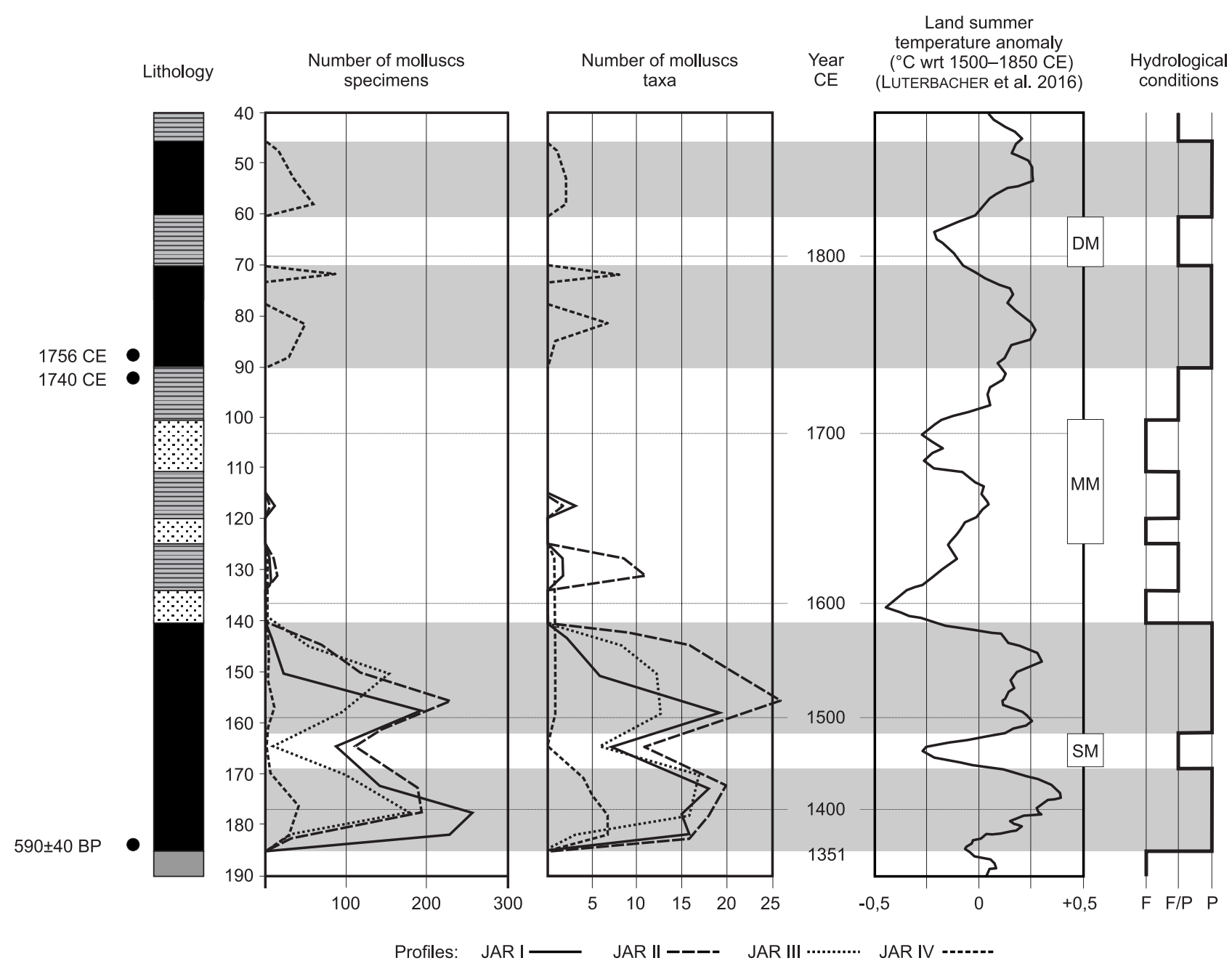

Fig. 7. Comparison of the number of specimens and mollusc taxa in millpond sediments with reconstructed European land summer temperature anomalies (with respect to 1500-1850 CE) for the period 1300-ca.1900 CE (LUTERBACHER et al. 2016).

The lithological profile is a combination of profile JAR I (bottom and middle part) and profile JAR IV (upper part) to which JAR II and JAR III profiles are attached. It was assumed that the bottom layer of brown-black muds is homogenous in terms of age in all profiles. Radiocarbon and dendrochronological dates after JONCZAK \& FLOREK (2013). Lithological signatures as in Fig. 2. SM - Spörer Solar Minimum (1440-1460), MM - Maunder Solar Minimum (1645-1715), DM - Dalton Solar Minimum (1790-1830). Hydrological conditions: $\mathrm{F}$ - fluvial, $\mathrm{F} / \mathrm{P}$ - fluvial/limnic, $\mathrm{P}$ - limnic (pond). Warm periods are greyed

tury (max. $+0.35{ }^{\circ} \mathrm{C}$ compared to the reference period 1500-1850, LUTERBACHER et al. 2016). The composition of mollusc assemblages suggests that after the construction of the earth dam in 1351 and establishment of the pond, the conditions soon became favourable for the malacofauna. Seventeen taxa with varied ecological requirements appeared almost simultaneously, confirming PIP's opinion (1986) regarding the large variation in the structure of mollusc assemblages observed in anthropogenic water bodies in the first phase of colonisation. WiLliams et al. (2008) also point out that rapid colonisation of ponds can be governed by three primary factors: type of substrate favouring development of malacofauna, lack of predators, and relatively low nutrient status.

During phase I, a total of 30 taxa of molluscs occurred, represented by 1,399 individuals of snails and bivalves, which suggests favourable conditions related to stagnant water and stable hydrological, edaphic, and thermal conditions. The analysis of Cladocera (NISKA 2013) also showed that during phase I the density of cladocerans representing 11 species was 3,880 ind. $/ \mathrm{cm}^{-3}$ of sediment and was the highest throughout the profile. Among the molluscs, the highest proportion was formed by species characteristic of permanent water bodies, and species typical of small, periodically disappearing and strongly vegetated water bodies. The proportion of the hygrophilous S. putris, reaching $7.9 \%$ during the phase, is also considerable.

An important indicator of warm phase $\mathrm{I}$ is Monachoides incarnatus, a Central- and South-EastEuropean species (WIKTOR 2004), and eurythermal species of warm phases (ALEXANDROWICZ 1987, 
JUŘIČKOVÁ et al. 2014). In the pond sediments, it occurs in the bottom part of profile JAR I (175-180 $\mathrm{cm})$ corresponding to the age ca. 1390-1410 CE, characterised by relatively high summer temperature $\left(+0.3{ }^{\circ} \mathrm{C}\right.$ compared to the reference period 1500-1850, LUTERBACHER et al. 2016).

Phase I I ( cold period; $1450-1490$ C E )

From 1450 to 1490 , a cooling period occurred related to the Spörer solar minimum with summer temperatures lower by $-0.25{ }^{\circ} \mathrm{C}$ compared to the period 1500-1850 (LUTERBACHER et al. 2016). According to POLACZKÓWNA (1925) and CAMENISCH et al. (2016), the years 1450-1500 in Central Europe were characterised by very frosty and long winters and cool springs and summers resulting in a pronounced seasonal cycle of temperature. A decrease in the mean annual temperature and the resulting deterioration of habitat conditions is manifested in profiles JAR I, JAR II, and JAR III at the depth of $160-170 \mathrm{~cm}$, as a considerable decrease in the number of mollusc taxa and individuals, reaching its minimum of six taxa and 14 individuals in profile JAR III (Fig. 7).

Within this phase, species associated with aquatic plants completely disappear (among others $V$. cristata, B. leachi, G. albus, G. crista, S. nitida, A. lacustris), suggesting the retreat of macrophytes caused by the shortening of the vegetative period. They are replaced by euryoecious species and drought-resistant species, among others P. planorbis, G. rossmaessleri, S. palustris, suggesting periodic lack of functioning of the pond during that cold period.

$\mathrm{Ph}$ a s e I I ( w a r m period;

$1490-1590$ C E )

After the cooling phase, the period 1490-1590 is characterised by an improvement in thermal $\left(+0.3{ }^{\circ} \mathrm{C}\right.$ compared to the reference period $1500-$ 1850, LUTERBACHER et al. 2016) and habitat conditions, and the reappearance of species from the initial period of the pond's existence (Fig. 7). The malacofauna of the period includes 32 taxa and 877 individuals, dominated by $B$. tentaculata (shells and opercula), R. labiata, A. lacustris, and plant-dwellers (G. albus, G. crista, H. complanatus, V. cristata, B. leachi, S. nitida).

The end of phase III is marked by an assemblage dominated by the bivalves $P$. nitidum, $P$. subtruncatum, $A$. anatina, and $S$. corneum inhabiting zones with weakly developed emergent and submerged vegetation. In the sediments of the millpond, it is an indicator of a new type of sedimentation, pointing to hydrological transformations, caused by humidification of climate and increase in the discharge rate of the Jarosławianka Stream.

\section{P hase IV ( cold period;} $1590-1715$ C E )

During this phase, an evident deterioration of habitat conditions is recorded, observed in the lithology and in the composition and structure of mollusc assemblages (Fig. 7). Black muds are replaced by river sands alternating with sandy and muddy sediments with laminar structure. Water level fluctuations and low water $\mathrm{pH}$ indicated by the presence of the acidophilous cladoceran Alonella excisa, which develops even at pH 5.5 (NISKA 2013), caused a considerable decrease in the number of molluscs to 64 individuals, and the cladoceran density to 500 ind. $/ \mathrm{cm}^{-3}$ of sediment. Profiles JAR III and JAR IV are completely devoid of molluscs. Only in profiles JAR I and JAR II, within sandy-muddy sediments at depths 115-120 and $125-135 \mathrm{~cm}$ (Fig. 7), aquatic fauna represented by 12 taxa was identified, among others $R$. labiata, shells and opercula of $B$. tentaculata, $V$. piscinalis, and $A$. anatina, $P$. casertanum, $P$. nitidum, $P$. subtruncatum.

The correlation of the mollusc frequency with the course of summer temperature in Europe (LUTERBACHER et al. 2016) shows that the middle and upper parts of this phase correspond with the Maunder Solar Minimum, characterised by considerable cooling (min. $-0.25^{\circ} \mathrm{C}$ compared to the period 1500-1850, LUTERBACHER et al. 2016) and humidification of the climate. This coldest period of the Little Ice Age (BRADLEY \& JONES 1993) is associated with glacier advancement in the Alps during the Fernau phase (BORTENSCHLAGER 1982), increase in the level of lakes in large areas of Europe (WOJCIECHOWSKI 2000, MAGNY et al. 2008), increase in fluvial activity (STARKEL 2000, MACKLIN et. al. 2006, HOFFMANN et al. 2008), and intensification of landslide processes in mountain areas (STARKEL 1986, ALEXANDROWICZ et al. 1997, ALEXANDROWICZ 2009). In the millpond in the Jarosławianka valley, the cooling of the climate is manifest as deposition of river sands, particularly ca. 1640-1650 CE, during the Late Maunder Minimum (1675-1715 CE), as well as ca. 1600 CE (Fig. 7).

Phase V (warm period; $1750-1790$ C E )

It was identified exclusively in profile JAR IV located in the northern part of the millpond at the depth of 70-90 cm, within the brown-black muds. It yielded 157 individuals representing 10 taxa, mostly $B$. tentaculata (opercula only), the remaining ones being S. putris, B. leachi, V. macrostoma, V. piscinalis, R. labiata, L. stagnalis, G. crista, Valvata sp. and Planorbidae indet. The composition of the malacofauna, and especially the presence of numerous opercula of $B$. tentaculata, corresponds with the shallow shore zone of the millpond covered by rich rush vegetation (ALEXANDROWICZ 
1999), as is also indicated by the high frequency of Cladocera living in the muddy bottom and among aquatic plants (NISKA 2013). The small number of species and the low diversity of the mollusc assemblages, compared to the previous warm phases, probably results from a higher level of water trophy, also confirmed by the high proportion of eutrophic-preferring cladoceran species, among others Leydigia acanthocercoides (NISKA 2013). Phase V should be associated with a warm period of $1750-1790$ with mean summer temperatures higher by $+0.25{ }^{\circ} \mathrm{C}$ compared to the period 1500-1850 (LUTERBACHER et al. 2016).

\section{Phase VI ( a f ter 1790 C E )}

After $1790 \mathrm{CE}$, a short period of considerable climate cooling occurs (min. $-0.25{ }^{\circ} \mathrm{C}$ compared to the period 1500-1850, LUTERBACHER et al. 2016), related to the Dalton Solar Minimum (1790-1830) (Fig. 7). In terms of lithology, the period corresponds with the sandy-muddy levels devoid of molluscs. The overlying layer of brown-black muds (depth 45-60 cm; ca. 1830-1870 CE) contains exclusively opercula of B. tentaculata and several individuals of B. leachi, which according to ALEXANDROWICZ (1999) suggests strong overgrowing of the pond.

The last stratigraphic unit is represented by a series of rapidly accumulated overbank deposits with a thickness of $30-90 \mathrm{~cm}$, and modern soil cover. The sediments are completely devoid of molluscs, or any other macrofossils. After ca. $1870 \mathrm{CE}$, the surface area of the pond largely decreased and the pond shifted northwards, outside the line of the analysed profile, as confirmed by a topographic map from that period (TOPOGRAPHISCHE KARTE 1891).

\section{RESPONSE OF MOLLUSC ASSEMBLAGES TO CLIMATE CHANGES}

The observed changes in the mollusc assemblages in the sediments of the millpond in the Jarosławianka Stream valley reflect important climate changes that occurred over the last 600 years. Warm periods alternated with cooling phases related to solar activity minima occurring in the periods: 1440-1460 CE (Spörer Minimum), 1645-1715 CE (Maunder Minimum), and 1790-1830 CE (Dalton Minimum) (LUTERBACHER et al. 2001, AMMANN et al. 2007, CAMENISCH et. al. 2016).

\section{CONCLUDING REMARKS}

The results of the analysis of mollusc assemblages from four profiles provided interesting information regarding a period of approximately six hundred years of functioning of the millpond in the Jarosławianka Stream valley. During its existence,
The mollusc assemblages of the millpond responded to climate changes with changes in the number of species and number of individuals (Fig. 7), as well as the structure, including variation in the percentage of plant-dwelling species. During warm periods, particularly in 1351-1450 and 1490-1590 $\mathrm{CE}$, the assemblages were characterised by high species diversity and abundance, and a high proportion of snail species living on muddy bottom and among aquatic vegetation (among others $V$. cristata, B. leachi, G. albus, G. crista, S. nitida, A. lacustris).

During cold periods, the number of species and individuals considerably decreased, the structure of assemblages was dominated by euryoecious species (V. piscinalis, B. tentaculata, R. labiata), and rheophilous species appeared due to an increase in the stream flow (A. anatina, S. corneum, $P$. nitidum, $P$. subtruncatum). Frosty and long winters and short and cool summers caused a reduction of the vegetative period of macrophytes, and therefore led to a decrease in the number, or even disappearance of plant-dwelling mollusc species. A similar correlation between mollusc assemblages and presence of macrophytes was observed in Lake Kojle (APOLINARSKA et al. 2018), where an increase in the number of submerged plant species during warm climatic phases promoted the development of most diverse and very abundant malacofauna, and the retreat of macrophytes in cool periods resulted in a decrease in the number of taxa and individuals of aquatic snails.

The phases of development of the millpond distinguished on the basis of mollusc assemblages are associated with climate changes and the co-occurring human economic activity. Cold and humid conditions in spring, summer, and autumn certainly negatively affected the volume of cereal production (CAMENISCH et. al. 2016), and consequently the volume of its processing into flour in mills. Due to this, as a result of reduced cereal harvests in cold periods (1450-1490 and 1590-1750 CE), the mill may have periodically discontinued its operation, and the millpond in the Jarosławianka Stream valley was probably drained of water. In lithological terms, these events are reflected by the layers of fluvial sands between the muds of the millpond (Fig. 7), and in faunistic terms by the mollusc assemblages including drought-resistant species and assemblages with rheophilous species.

the pond was a shallow water body inhabited by a diverse malacofauna.

The mollusc assemblages occurring in the sediments of the millpond point to the cyclic character of ecological transformations, primarily resulting from 
environmental changes. The records of the frequency of molluscs evidently point to favourable conditions during warm phases I (1351-1450 CE), III (14901590 CE), V (1750-1790 CE) and VI (ca. 1830-1870 $\mathrm{CE}$ ) featuring stagnating water, stable hydrological factors, temperate thermal conditions, and abundance of nutrients. The warm phases alternated with periods of unfavourable conditions.

The sediments of the millpond in the Jarosławianka Stream valley show a very strong correlation between the lithological record, species composition and structure of mollusc assemblages, and thermal conditions (LUTERBACHER et al. 2016), permitting the determination of the hydrological conditions of the pond. According to our study, the pond was fully functional in the warm periods, during phases I, III, and $\mathrm{V}$, as well as in the period ca. 1830-1870 CE; in the cold periods, as a result of a limited operation of the mill, it was probably emptied. The lack of historical sources, however, makes it impossible to confirm this scenario.

The millpond in the Jarosławianka Stream valley is a unique site providing a good, continuous record of environmental transformations, with substantial climatic changes reflected in the record of mollusc assemblages.

\section{ACKNOWLEDGEMENTS}

We are grateful to the three anonymous reviewers for their valuable comments and suggestions which allowed us to improve the manuscript.

\section{REFERENCES}

AlEXANDROWICZ S. W. 1987. Analiza malakologiczna w badaniach osadów czwartorzędowych. Kwartalnik AGH, Geologia 12: 3-240.

AlEXANDROWICZ S. W. 1999. Bithynia tentaculata (Linnaeus, 1757) as an indicator of age and depositional environment of Quaternary sediments. Folia Malacologica 7: 79-88. https://doi.org/10.12657/folmal.007.007

AleXANDROWICZ S. W., ALEXANDROWICZ W. P. 2011. Analiza malakologiczna. Metody badań i interpretacji. Polska Akademia Umiejętności, Kraków.

AleXANDrowicz S. W., AleXANDrowicz W. P., KrąPIEC M., SZYCHOWSKA-KRĄPIEC E. 1997. Environmental changes of Southern Poland during historical period. Kwartalnik AGH, Geologia 23: 339-387.

AlEXANDROWICZ W. P. 2009. Malakofauna i fazy rozwoju osuwiska w Tylce koło Krościenka (Pieniny). Kwartalnik AGH, Geologia 35: 69-75.

AMmANn C. M., Joos F., SCHIMEl D. S., OTTO-Bliesner B. L., TOMAS R. A. 2007. Solar influence on climate during the past millennium: Results from transient simulations with the NCAR Climate System Model. Proceedings of the National Academy of Sciences of the United States of America 104: 3713-3718. https://doi. org/10.1073/pnas.0605064103

APOLINARSKA K., OBREMSKA M., AUNINAC L., GAEKA M. 2018. Response of the aquatic plants and mollusc communities in Lake Kojle (central Europe) to climatic changes between $250 \mathrm{BCE}$ and $1550 \mathrm{CE}$. Aquatic Botany 148: 35-45. https://doi.org/10.1016/j. aquabot.2018.04.004

BORTENSCHLAGER S. 1982. Chronostratigraphic subdivision of the Holocene in the Alps. Striae 16: 75-79.

Bradley R. S., JONES P. D. 1993. 'Little Ice Age' summer temperature variations: their nature and relevance to recent global warming trends. The Holocene 3: 367376. https://doi.org/10.1177/095968369300300409

BRONK RAMSEY C. 2009. Bayesian analysis of radiocarbon dates. Radiocarbon 51: 337-360. https://doi. org/10.1017/S0033822200033865
CAmenisch C., Keller K. M., SAlvisberg M., AmanN B., BAUCH M., BLUMER S., BRÁZDIL R., BRÖNNIMANN S., BÜNTGEN U., CAMPBELl B. M. S., FERNÁNDEZ DONADO L., Fleitmann D., Glaser R., GONZÁlez Rouco F., Grosjean M., HOFFMANN R. C., HuHTAMAa H., JoOS F., KisS A., KOTYZA O., LEHNER F., LUTERbACHER J., Maughan N., NeUKom R., Novy T., Pribyl K., Raible C. C., Riemann D., SCHUH M., SlaVin P., WERnER J. P., WETTER O. 2016. The 1430s: a cold period of extraordinary internal climate variability during the early Spörer Minimum with social and economic impacts in northwestern and central Europe. Climate of the Past 12: 2107-2126. https://doi.org/10.5194/cp-12-2107-2016

CÉRÉghiNo R., Biggs, J., OeRTli B., DeClerCK S. 2008. The ecology of European ponds: defining the characteristics of a neglected freshwater habitat. Hydrobiologia 597: 1-6. https://doi.org/10.1007/s10750-007-9225-8

FLOREK W., TYLMAN I. 2013. Skaning laserowy w badaniach morfologicznych małych dolin rzecznych (przypadek doliny Jarosławianki). In: JONCZAK J., FLOREK W. (eds). Środowisko glebotwórcze i gleby dolin rzecznych. Bogucki Wydawnictwo Naukowe, Poznań, pp. 19-32.

GRIMM E. C. 1990. TILIA and TILIA.GRAPH. PC spreadsheet and graphics software for pollen data. INQUA Working Group on Data-Handling Methods Newsletter 4: 5-7.

Hammer Ø., Harper D. A. T., RYAN P. D. 2001. Past: paleontological statistics software package for education and data analysis. Palaeontologia Electronica 4: 1-9.

HofFMANN T., LANG A., DiKAU R. 2008. Holocene river activity: analysing ${ }^{14} \mathrm{C}$-dated fluvial and colluvial sediments from Germany. Quaternary Science Reviews 27: 20312040. https://doi.org/10.1016/j.quascirev.2008.06.014

JONCZAK J. 2010. Właściwości sorpcyjne i buforowe gleb nisz źródliskowych w dolinie Jarosławianki (Równina Sławieńska). Roczniki Gleboznawcze 61: 47-53.

JONCZAK J., FlOREK W. 2013. Wiek i właściwości gleb wykształconych $\mathrm{z}$ osadów stawu młyńskiego $\mathrm{w}$ dolinie Jarosławianki (Równina Sławieńska). In: JoNCZAK 
J., FLOREK W. (eds). Środowisko glebotwórcze i gleby dolin rzecznych. Bogucki Wydawnictwo Naukowe, Poznań, pp. 33-40.

JUŘiČKOVÁ L., LOŽEK V., HORÁČKOVÁ J., TLACHAČ P., HORÁČEK I. 2014. Holocene succession and biogeographical importance of mollusc fauna in the Western Sudetes (Czech Republic). Quaternary International 353: 210-224. https://doi.org/10.1016/j. quaint.2013.02.029

KoŁodZIEJCZYK A., DoŁęGA A. E. 2004. Molluscs of selected water bodies in Warsaw. Folia Malacologica 12: 63-71. https://doi.org/10.12657/folmal.012.003

KONDRACKI J. 2009. Geografia regionalna Polski. PWN, Warszawa.

LOŽEK V. 1964. Quartärmollusken der Tschechoslowakei. Rozpravy Ustředniho Ustavu Geologického 31: 1-374.

Luterbacher J., RiCKli R., Xoplaki E., Tinguely C., BeCK C., Pfister C., WANNer H. 2001. The Late Maunder Minimum (1675-1715) - a key period for studying decadal scale climatic change in Europe. Climatic Change 49: 441-462.

Luterbacher J., Werner J., SMERdon J., FERnANDEZDONADO L., GONZALEZ-ROUCO F., BARRIOPEDRO D., LJUNGQVIST F., BUENTGEN U., ZORITA E., WAGNER S., Esper J., McCarroll D., TOReti A., FranK D., JungClaus J., Barriendos M., Bertolin C., BOthe O., BRAZDIL R., CAMUfFO D., DOBROVOlNY P., Gagen M., Garica-Bustamante E., Ge Q., GomeZNavarro J., Guiot J., HaO Z., Hegerl G., Holmgren K., Klimenko V., Martin-Chivelet J., Pfister C., ROBERTS N., SCHINDLER A., SCHURER A., SOLOMINA O., VON GUNTEN L., WAHL E., WANNER H., WeTter O., XOPlaki E., YUAN N., ZANCheTtiN D., ZHANG H., ZEREFOS C. 2016. European summer temperatures since Roman times. Environmental Research Letters 11: 1-12. https://doi.org/10.1088/17489326/11/2/024001

Macklin M. G., Benito G., Gregory K. J., JOHnStOne E., LEWIN J., MiCHCZYŃSKA D. J., SOJA R., STARKEL L., THORNDYCRAFT V. R. 2006. Past hydrological events reflected in the Holocene fluvial record of Europe. Catena 66: 145-154. https://doi.org/10.1016/j.catena.2005.07.015

Magny M., Gauthier E., VAnNière B., Peyron O. 2008. Palaeohydrological changes and human-impact history over the last millennium recorded at Lake Joux in the Jura Mountains, Switzerland. Holocene 18: 255-265. https://doi.org/10.1177/0959683607086763

NiSKA M. 2013. Ewolucja stawu młyńskiego w dolinie Jarosławianki w świetle analizy kopalnych szczątków Cladocera (Crustacea). In: JONCZAK J., FlOREK W. (eds). Środowisko glebotwórcze i gleby dolin rzecznych, Bogucki Wydawnictwo Naukowe, Poznań, pp. 103-112.

PIP E. 1986. A study of pond colonization by freshwater molluscs. Journal of Molluscan Studies 52: 214-224. https://doi.org/10.1093/mollus/52.3.214

PLIT J. 2009. Przestrzenne zmiany użytkowania gruntów na Ziemi Sławieńskiej w ciągu ostatnich 400 lat. In: RĄCZKOWSKI W., SROKA J. (eds). Historia i kultura
Ziemi Sławieńskiej, 9. Fundacja „Dziedzictwo”, Sławno, pp. 93-112.

POLACZKÓWNA M. 1925. Wahania klimatyczne w Polsce w wiekach średnich (Climatic variations in Poland during the Middle Ages). Prace Geograficzne 5: 1-80.

RĄCZKOWSKI W., BANASZEK Ł. 2013. Osadnictwo w rejonie Jarosławianki - problemy badawcze. In: JoNCZAK J., FlOREK W. (eds). Środowisko glebotwórcze i gleby dolin rzecznych. Bogucki Wydawnictwo Naukowe, Poznań, pp. 113-122.

Reimer P. J., Austin W. E. N., BARd E., Bayliss A., BlaCKWEll P. G., BRONK RAMSEY C., ButZiN M., ChENG H., EdWARdS R. L., FrIEDriCH M., GroOtes P. M., Guilderson T. P., Hajdas I., HEATON T. J., Hogg A. G., Hughen K. A., Kromer B., MANNing S. W., Muscheler R., Palmer J. G., Pearson C., VAN DER Plicht J., ReIMER R. W., Richards D. A., SCOTT E. M., SOUTHON J. R., TURNEY C. S. M., WACKER L., AdOlPhi F., BÜNTGEN, U., CAPANO M., FAHRNi S. M., FOGTMANN-SCHUlZ A., FRIEDRICH R., KÖHLER P., KudSK S., MiYAKE F., OlSEN J., REINIG F., SAKAMOTO M., SOOKDEO A., TALAMO S. 2020. The IntCal20 Northern Hemisphere radiocarbon age calibration curve (055 cal kBP). Radiocarbon 62: 725-757. https://doi. org/10.1017/RDC.2020.41

RosENOW K. 1934. Altkrakow. Ost Heimat. Rügenwalde Zeitung: 32-34, Rügenwalde.

SoBISZ Z. 2013. Flora naczyniowa zlewni Jarosławianki (Równina Sławieńska). In: JONCZAK J., FLOREK W. (eds). Środowisko glebotwórcze i gleby dolin rzecznych, Bogucki Wydawnictwo Naukowe, Poznań, pp. 135-142.

SPYRA A., SERAFIŃSKI W., STRZELEC M. 2007. The species diversity of freshwater snails (Gastropoda) in differently managed fish ponds in South-Western Poland. Ekológia 26: 83-89.

STARKEL L. 1986. Holocene climatic changes reflected in the slope and valley floor evolution in European mountains. Studia Geomorphologica Carpatho-Balcanica 20: 49-56.

STARKEL L. 2000. Chronology of phases of various fluvial activity, of erosion and deposition in the Vistula catchment during Late Quaternary. Geochronometria 19: 53-58.

STRZELEC M. 1993. Ślimaki (Gastropoda) antropogenicznych środowisk wodnych Wyżyny Śląskiej. Prace Naukowe Uniwersytetu Śląskiego 1358: 1-104.

STRZELEC M., KRODKIEWSKA M., KRÓlCZYK A. 2014. The impact of environmental factors on the diversity of gastropod communities in sinkhole ponds in a coal mining region (Silesian Upland, Southern Poland). Biologia 69: 780-789. https://doi.org/10.2478/s11756-014-0369-5

STRZELEC M., SERAFIŃSKI W. 2004. Biologia i ekologia ślimaków w zbiornikach antropogenicznych. Centrum Dziedzictwa Przyrody Górnego Śląska, Katowice.

SZWARCZEWSKI P. 2003. Zapis naturalnych i antropogenicznych zmian środowiska przyrodniczego w okolicach Żyrardowa na przykładzie osadów wypełniających nieckę stawu młyńskiego. In: WAGA J. M., KoCEL K. (eds). Człowiek w środowisku przyrodniczym - zapis 
działalności. PTG Oddział Katowicki, Sosnowiec, pp. 213-219.

TOPOGRAPHISCHE KARTE 1891. Topographische Karte 1:25 000, Grupenhagen (Meßtischblatt 318). Königlich Preußische Landesaufnahme, Berlin.

WIKTOR A. 2004. Ślimaki lądowe Polski. Mantis, Olsztyn.

Williams P., WhitFiEld M., BigGS J. 2008. How can we make new ponds biodiverse? A case study monitored over 7 years. In: CÉRÉGHINO R., BIGGS J., OERTLI B., DECLERCK S. (eds). The ecology of European ponds: defining the characteristics of a neglected freshwater habitat. Hydrobiologia 597: 137-148. https://doi. org/10.1007/s10750-007-9224-9
WOJCIECHOWSKI A. 2000. Zmiany paleohydrologiczne W środkowej Wielkopolsce w ciągu ostatnich 12000 lat w świetle badań osadów jeziornych rynny kórnickozaniemyskiej. Wydawnictwo Naukowe UAM, Poznań.

WOOD P. J., BARKER S. 2000. Old industrial mill ponds: a neglected ecological resource. Applied Geography 20: 6581. https://doi.org/10.1016/S0143-6228(99)00015-6

Received: July 23rd, 2020

Revised: November 11th, 2020

Accepted: November 23rd, 2020

Published on-line: December 4th, 2020 